Kumawula, Vol. 2, No.3, Desember 2019, Hal 236 - 247 DOI:http://10.24198/kumawula.v1i3.24553

ISSN 2620-844X (online)

Tersedia online di http://jurnal.unpad.ac.id/kumawula/index

\title{
PENGEMBANGAN EKOWISATA BERBASIS MASYARAKAT DI DESA TARUMAJAYA, HULU SUNGAI CITARUM: POTENSI DAN HAMBATAN
}

\author{
Oekan Soekotjo Abdoellah ${ }^{1}$, Sunardi ${ }^{2}$, Ida Widianingsih ${ }^{3}$, Martha Fani Cahyandito ${ }^{4}$, \\ Dede Tresna Wiyanti ${ }^{5}$, Hardian Eko Nurseto ${ }^{6}$ \\ ${ }^{1}$ Departemen Antropologi FISIP dan Pusat Unggulan Lingkungan dan Ilmu Keberlanjutan UNPAD, \\ ${ }^{2}$ Departemen Biologi FMIPA dan Pusat Unggulan Lingkungan dan Ilmu Kerlanjutan - UNPAD, \\ ${ }^{3}$ Pusat Studi Desentralisasi dan Pembangunan Partisipatif, FISIP Unpad, \\ ${ }^{4}$ Fakultas Ekonomi dan Bisnis Universitas Padjadjaran, \\ ${ }^{5,6}$ Departemen Antropologi Fakultas Ilmu Sosial dan Ilmu Politik Universitas Padjadjaran \\ 1'oekan@unpad.ac.id,2sunardi@unpad.ac.id, ${ }^{3 i d a . w i d i a n i n g s i h @ u n p a d . a c . i d, ~}$ \\ 4martha.fani.cahyandito@gmail.com, 5dedettresna2018@gmail.com, ${ }^{6}$ hardian.e.nurseto@unpad.ac.id
}

\begin{abstract}
ABSTRAK
Pengembangan ekowisata merupakan salah satu upaya pemanfaatan sumberdaya lokal yang optimal. Sejalan dengan praktek ekowisata berbasis masyarakat, konsep pariwisata berbasis masyarakat ini merupakan sebuah konsep pariwisata yang menekankan pada sisi pengembangan masyarakat dalam mengelola pariwisata yang ada. Konsep ini sering disebut community based tourism (CBT). Metode kualitatif dan kuantitatif digunakan untuk melihat CBT di Desa Tarumajaya. Desa Tarumajaya memiliki berbagai potensi pengembangan ekowisata. Beberapa potensi wisata di antaranya Situ Cisanti, Curug Lodaya Barat, Situs Batu Korsi, Situs Batu Kasur, Air Panas Ciseke, Situs Batu Lingga, Wisata Gunung Wayang, dan Wisata Edukasi berbasis alam. Meskipun elemen-elemen kunci Community Based Tourism sudah dilakukan dalam praktek ekowisata di Desa Tarumajaya, namun belum memadai. Berbagai usaha masih harus dilakukan, terutama agar ekowisata di Desa Tarumajaya mampu memberikan alternative sumber matapencaharian bagi warga, yang notabene adalah petani tanpa lahan. Kegiatan ekowisata yang berlandaskan CBT diharapkan mampu mengurangi ketergantungan warga atas lahan, terutama lahan konservasi.
\end{abstract}

Kata kunci: Community Based Tourism, Ecotourism, Tarumajaya, Citarum Hulu

\section{DEVELOPMENT OF A COMMUNITY BASED ECOTOURISM IN TA- RUMAJAYA VILLAGE, UPSTREAM CITARUM RIVER: POTENTIALS AND OBSTACLES}

\begin{abstract}
Ecotourism development is one of the most optimal efforts to utilize local resources. In line with the practice of community-based ecotourism, the concept of community-based tourism is a concept of tourism that emphasizes the side of community development in managing existing tourism. This concept is often called community based tourism (CBT). Qualitative and quantitative methods are used to view CBT in Tarumajaya Village. Tarumajaya Village has a variety of ecotourism development potential.
\end{abstract}


Some tourism potentials include Situ Cisanti, Lodaya Barat Curug, Korsi Batu Site, Batu Kasur Site, Ciseke Hot Springs, Batu Lingga Site, Gunung Wayang Tourism, and Nature-based Educational Tourism. Although the key elements of Community Based Tourism have been carried out in the practice of ecotourism in Tarumajaya Village, it has not been sufficient. Various efforts still have to be done, especially so that ecotourism in Tarumajaya Village is able to provide alternative sources of livelihood for residents, who are landless farmers. Ecotourism activities based on CBT are expected to reduce people's dependence on land, especially on conservation land.

Keywords: Community Based Tourism, Ecotourism, Tarumajaya, Citarum Hulu

\section{Pendahuluan}

Pengembangan ekowisata merupakan salah satu upaya pemanfaatan sumberdaya lokal yang optimal. Dalam konteks ini wisata yang dilakukan memiliki bagian yang tidak terpisahkan dengan upaya-upaya konservasi, pemberdayaan ekonomi lokal dan mendorong respek yang lebih tinggi terhadap perbedaan kultur atau budaya. Ekowisata menghubungkan antara perjalanan wisata alam yang memiliki visi dan misi konservasi dan kecintaan terhadap lingkungan. Hal ini dapat terjadi karena keuntungan finansial yang didapat dari biaya perjalanan wisata digunakan juga untuk kebutuhan konservasi alam serta perbaikan kesejahteraan penduduk lokal.

Pergeseran konsep kepariwisataan dunia ke model ekowisata, disebabkan karena kejenuhan wisatawan untuk mengunjungi obyek wisata buatan. Oleh karena itu peluang ini selayaknya dapat dimanfaatkan secara maksimal untuk menarik wisatawan mengunjungi objek berbasis alam dan budaya penduduk lokal.

Dalam perkembangan kepariwisataan secara umum, muncul pula istilah sustainable tourism atau "wisata berkelanjutan". Wisata berkelanjutan dipandang sebagai suatu langkah untuk mengelola semua sumber daya yang secara sosial dan ekonomi dapat dipenuhi dengan memelihara integritas budaya, proses-proses ekologi yang mendasar, keragaman hayati, dan unsurunsur pendukung kehidupan lainnya". Berdasarkan pemahaman diatas, maka pariwisata dipandang sebagai salah satu alternatif untuk meningkatkan pendapatan daerah. Apalagi pengoptimalan potensi ini didasari bahwa pariwisata merupakan sektor yang lebih menekankan pada penyediaan jasa dengan mengoptimalkan potensi kawasan wisata.

Sejalan dengan praktek ekowisata berbasis masyarakat, konsep pariwisata berbasis masyarakat ini merupakan sebuah konsep pariwisata yang menekankan pada sisi pengembangan masyarakat dalam mengelola pariwisata yang ada. Konsep ini sering disebut community based tourism (CBT). Perbedaan pariwisata biasa dengan CBT adalah adanya tujuan lain dari pariwisata, yang bukan semata-semata sebagai bisnis dan mendapatkan keuntungan sebesar- 
besarnya dari investor atau pengunjung, melainkan sebagai sarana untuk menguatkan suatu organisasi sosial masyarakat dalam mengatur sumber daya pariwisata dengan partisipasi langsung dari warga lokal (Suansri, 2003). Sementara menurut Dodds (2016), pelaksanaan CBT ditandai dengan enam elemen berikut ini:

1. Perencanaan partisipatif dan pengembangan daya dukung untuk memperkuat keterampilan manajemen pariwisata masyarakat. Meliputi pelatihan seperti pemandu wisata, bahasa, komunikasi, produksi kerajinan tangan, kebersihan dan keselamatan. Kesiapan masyarakat dalam menghadapi pasar yang terbuka dan kompetitif, transformasi dari penerima manfaat menjadi manajer bisnis mengidentifikasi kekompakan (atau kebersamaan), karena pariwisata yang begitu dekat dengan rumah, dapat menciptakan ketegangan dan konflik, dan kemampuan anggota komunitas untuk bekerja bersama dan evaluasi perencanaan.

2. Adanya kolaborasi dan kemitraan yang menguhubungkan ke target pasar untuk memastikan kelangsungan keuangan. Meliputi berbagai model kolaborasi mulai dari kemitraan publik ke sektor swasta dan usaha patungan. Misalnya, dengan bermitra dengan perusahaan tur domestik atau internasional yang membeli produk atau layanan pariwisata, atau afiliasi dengan pasar menciptakan keterkaitan pasar pada tahap perencanaan yang dapat membantu mengembangkan product siap-pasar. Banyak bentuk pemasaran yang sukses oleh CBT adalah kemitraan atau jaringan dengan operator tur luar, yang menekankan pentingnya kolaborasi. Sementara mungkin lebih bermanfaat untuk mengadopsi pendekatan otonom, kenyataannya adalah bahwa komunitas-komunitas ini tidak memiliki keterampilan atau sumber daya untuk dapat memasarkan barang dan jasa mereka untuk menarik wisatawan (Mtapuri \& Giampiccoli, 2013, dalam R. Dodds, A. Ali, K. Galaski, 2016).

3. Pemberdayaan masyarakat lokal. Upaya ini dilakukan dengan melibatkan unsur-unsur manajemen lokal karena pemberdayaan CBT tidak dapat dilepaskan dari unsur-unsur pengembangan kapasitas dan pendekatan partisipatif dari proses pengembangan CBT. Manajemen lokal, meskipun dikatakan sebagai faktor penting CBT, sering dikecewakan oleh kemampuan nyata para peserta untuk mengelola bisnis pariwisata.

4. Berorientasi pada nilai-nilai lingkungan dan pengembangan masyarakat. Unsur ke empat ini bertujuan agar pariwisata dapat terlaksana secara berkelanjutan. Upaya lingkungan umum termasuk proyek konservasi, pengelolaan limbah, air dan energi, inventarisasi flora dan fauna untuk interpretasi alam, berkebun dan pertanian organik, reboisasi, menggunakan bahan alami dan daur ulang yang alami dan berkelanjutan. Adapun upaya 
sosial dan ekonomi meliputi membantu membangun sekolah, menyuplai air untuk penduduk, meningkatkan kewirausahaan mikro, melatih penduduk setempat untuk menjadi pemandu, mempekerjakan keluarga pribumi untuk berbagi pengetahuan dengan pengunjung dan sumbangan sekolah. Upaya-upaya ini adalah kunci dalam meningkatkan citra ekowisata dan mencapai tujuan yang digariskan oleh anggota masyarakat.

5. Bantuan dari enabler (pemerintah, lembaga pendanaan dan sektor swasta). CBT bukan pariwisata yang terlaksana tanpa membutuhkan bantuan dari pihak lain. Kehadiran para enabler, baik itu pemerintah maupun pihak swasta, berpotensi untuk memberikan fasilitas akses ke ekonomi formal. Para enabler dapat mengambil peran pada cakupan pemasaran, pelatihan atau pendanaan dan struktur institusional, program pendanaan dan kemitraan.

6. Memberi pendapatan bagi masyarakat lokal dalam jangka panjang. Kehadiran pariwisata yang dikelola oleh warga lokal dalam satu kawasan tertentu, diharapkan dapat menunjang pendapatan mereka. Kedatangan wisatawan bisa menjadi potensi pasar terkait produk atau jasa yang disediakan oleh warga yang tinggal di sekitar area wisata. Jadi, pendapatan ini tidak hanya sekali atau dua kali tetapi menjadi pendapatan yang menjanjikan bagi mereka. Desa Tarumajaya memiliki berbagai potensi pengembangan ekowisata. Beberapa potensi wisata di antaranya Situ Cisanti, Curug Lodaya Barat, Situs Batu Korsi, Situs Batu Kasur, Air Panas Ciseke, Situs Batu Lingga, Wisata Gunung Wayang, dan Wisata Edukasi berbasis alam. Letak potensi-potensi wisata ini tersebar di sejumlah dusun di Desa Tarumajaya seperti di Dusun Pilar, dan Dusun Kertasari.Desa Tarumajaya adalah desa yang penting bagi Daerah Aliran Sungai (DAS) Citarum. Situ Cisanti yang merupakan titik kilometer 0 hulu Sungai Citarum berada di wilayah Desa Tarumajaya.

Saat ini pengembangan wisata di Desa Tarumajaya masih ada pada tahap awal. Oleh karena itu, pengembangan CBT dirasa sangat tepat, sehingga keterlibatan masyarakat dapat dilakukan sejak awal pengembangan program pariwisata. Secara geografis, wilayah Desa Tarumajaya berada di dataran tinggi $1.700 \mathrm{mdpl}$, dengan udara yang sejuk dengan rata-rata temperature $24^{\circ} \mathrm{C}$. Desa ini juga memiliki lahan yang cukup luas, yaitu 2.743,80 hektar. Sebagian besar lahan di wilayah Desa Tarumajaya adalah lahan hutan, perkebunan, dan lahan pertanian komersial.

\section{Metode}

Penelitian ini menggunakan metode penelitian kualitatif dan kuantitatif. Instrumen pengumpulan data menggunakan observasi, wawancara, dan dokumentasi. Observasi dan survey dil- 
akukan langsung di Desa Tarumajaya pada Bulan September dan Oktober 2019. Survey dilakukan terhadap 97 responden, dengan sebaran sebagai berikut:

Tabel 1. Sebaran Responden di Desa Tarumajaya

\begin{tabular}{|l|r|r|}
\hline \multicolumn{1}{|c|}{ Kampung } & Jumlah & \multicolumn{1}{c|}{$\%$} \\
\hline Goha1 & 14 & 14.4 \\
\hline Goha 2 & 14 & 14.4 \\
\hline Pilar 2 & 15 & 15.5 \\
\hline Lodaya & 14 & 14.4 \\
\hline Kertasari 1 & 13 & 13.4 \\
\hline Kertasari 2 & 14 & 14.4 \\
\hline Citawa & 13 & 13.4 \\
\hline Total & 97 & 100.0 \\
\hline
\end{tabular}

Sumber: Survey, 2019

\section{Kondisi Sosial dan Ekonomi}

Desa Tarumajaya memiliki jumlah penduduk kedua terbesar di Kecamatan Kertasari Kabupaten Bandung. Mayoritas mata pencaharian penduduk di Desa Tarumajaya adalah sebagai buruh tani. Sebanyak 4.560 Kepala Keluarga (KK) yang ada di Desa Tarumajaya, 2.623 anggota keluarga menjadi buruh tani, sehingga sumber penghasilan utama sebagian besar penduduk adalah buruh tani (Badan Pusat Statistik Kabupaten Bandung, 2017). Hasil survey juga menunjukkan bahwa sebagian besar warga merupakan petani yanpa tanpa lahan.

Tabel 2. Pemilikan Lahan Pertanian Di Desa Tarumajaya

\begin{tabular}{|l|r|r|}
\hline \multicolumn{1}{|c|}{ Jenis Lahan } & Jumlah & \multicolumn{1}{c|}{$\%$} \\
\hline Kebun & 9 & 9.28 \\
\hline Kebun di Talun & 1 & 1.03 \\
\hline Kebun di atas lahan Perhutani & 13 & 13.40 \\
\hline Tidak punya lahan & 74 & 76.29 \\
\hline Jumlah & 97 & 100.00 \\
\hline
\end{tabular}

Sumber: Survey, 2019

Meskipun masyarakat Desa Tarumajaya adalah masyarakat petani, hasil survey menunjukkan terdapat berbagai jenis pekerjaan lain yang dilakukan warga. 
Tabel 3 Jenis Pekerjaan di Desa Tarumajaya

\begin{tabular}{|l|r|r|}
\hline Jenis Pekerjaan & Jumlah & \multicolumn{1}{c|}{$\%$} \\
\hline Petani & 9 & 9.3 \\
\hline Pensiunan & 7 & 7.2 \\
\hline Lainnya & 12 & 12.4 \\
\hline Buruh Tani & 5 & 39.2 \\
\hline Buruh Pabrik & 3 & 5.2 \\
\hline Ternak & 4 & 4.1 \\
\hline Pegawai Swasta & 6 & 6.2 \\
\hline Pengusaha & 5 & 5.2 \\
\hline Pedagang & 8 & 8.2 \\
\hline Buruh Serabutan & 97 & 100.0 \\
\hline Total & & \\
\hline
\end{tabular}

Sumber: Survey, 2019

Hasil survey juga menujukkan bahwa sebagian besar warga bekerja sebagai buruh tani. Hal ini sesuai dengan hasil survey atas pemilikan lahan yang menunjukkan hanya sekitar 10\% warga yang memiliki lahan.

\section{Ekowisata di Tarumajaya}

Di antara beberapa potensi wisata yang berhasil diidentifikasi, yang sudah berjalan hingga saat ini adalah Situ Cisanti. Lokasinya berada di kawasan Perhutani di jalur menuju perkebunan teh. Kawasan Situ Cisanti disahkan menjadi kawasan wisata pada tahun 2018 yang sekaligus menjadi titik $0 \mathrm{~km}$ Sungai Citarum. Sebelum menjadi lokasi wisata, kawasan ini hanya perhutanan yang tidak diolah dengan baik. Ada beberapa mata air di sana seperti Cikole dan Cihanjuang yang sempat rusak pada tahun 1999-2001 dan mengalami kerusakan parah di tahun 2001-2002. Kerusakan ini disebabkan oleh hancurnya perkebunan di bagian atas, yang menyebabkan tanaman sayuran yang ditanam di sana, yakni wortel dan kentang, hanyut terbawa air hujan. Kejadian ini juga membuat air panas tercemar pestisida bawaan dari lahan perkebunan tersebut. Menanggapi potensi dari Situ Cisanti, pemerintah mengadakan program Citarum Harum terhitung sejak tahun 2018 - 2025. Setiap anggota TNI yang dilibatkan dalam 
program ini memiliki 70 sektor komando di beberapa titik di Desa Tarumajaya. Mereka melakukan pembibitan di area perkebunan dan melakukan pemeliharaan di Situ Cisanti. Segala aktivitas yang ada di Situ Cisanti dilakukan oleh TNI, dimulai dari penjagaan loket tiket sampai pengamanan dan pengelolaan.

Penduduk lokal tidak dilibatkan untuk aktivitas pengelolaan tersebut. Partisipasi mereka menjadi pengunjung atau berjualan di area pintu masuk. Setiap pengunjung dikenakan harga tiket masuk masing-masing Rp. 4.000 untuk parkir motor, Rp. 7.500 untuk parkir mobil, dan Rp. 10.000 untuk setiap orang yang masuk. Sebenarnya ada pengecualian untuk tiket masuk per orang, penduduk lokal biasanya hanya dikenakan biaya parkir tanpa dihitung biaya per orang. Hanya wisatawan yang berasal dari luar atau dianggap terlihat seperti wisatawan (misalnya membawa mobil rombongan) yang dikenakan tiket masuk. Ciri khas dari penduduk lokal adalah mereka datang dengan berjalan kaki, atau membawa motor tetapi tidak mengenakan helm.

Meskipun penanganan dilakukan oleh TNI dan tidak melibatkan penduduk desa secara langsung, tetapi hubungan kerjasama sudah terjalin. Kerjasama ini antara pemerintah desa, Perhutani, dan pengelola Cisanti yang menerapkan sistem bagi hasil masing-masing $30: 20$ : 50 untuk pengelola Situ Cisanti, pemerintah desa, dan Perhutani. Bagi hasil ini diserahkan setiap bulan. Pihak desa yang menerima ini adalah pengelola kelompok sadar wisata (pokdarwis) dengan nominal bagi hasil yang didapatkan adalah sekitar Rp. 800.000 - Rp. 1.000 .000 setiap bulannya.

Selain wisata Situ Cisanti, kegiatan pariwisata lainnya yang sudah mulai dilaksanakan adalah paket wisata edukasi berbasis alam yang dilakukan di Dusun Kertasari 2 atau biasa disebut oleh penduduk lokal sebagai kawasan Babakanranca. Kegiatannya meliputi pelatihan mengolah sampah, membuat biogas, wisata peternakan seperti memerah sapi, berkebun, dan membuat denah kampung. Kegiatan ini dilakukan selama 3 hari 4 malam. Paket wisata edukasi ini masih belum terintegrasi dengan pemerintah desa sehingga masih dikelola sendiri oleh seorang koordinator di Babakanranca. Kelangsungan program ini dimulai sejak 2014 dan terakhir kunjungan pada 2018. Memang belum terlalu konsisten tetapi seperti sudah mendapat klien tetap karena pada kegiatan di tahun 2014, 2016, dan 2018 merupakan peserta yang sama yang berasal dari SMP Semifalar.

Kegiatan wisata edukasi ini digagas oleh komunitas Institut Gunung Wayang (IGW) yang tujuan awalnya adalah untuk mengatasi permasalahan lingkungan seperti pengelolaan sampah dan pengelolaan kotoran sapi dari ternak sapi di sana. Kegiatan ini masih berlangsung 
meskipun tidak ada kegiatan pariwisata. Dalam melaksanakan program ini, komunitas IGW telah memiliki jejaring dengan berbagai pihak, salah satunya adalah menandatangani kontrak kerjasama dengan CSR dari Astra Indonesia dengan memberikan bantuan berupa dana untuk melaksanakan program. Kerjasama ini berlangsung selama satu tahun sejak September 2019 hingga September 2020.

Untuk menunjang kelangsungan kegiatan wisata edukasi berbasis alam ini, warga Babakanranca menyediakan fasilitas menginap yang diperuntukkan selama 3 hari 4 malam oleh peserta wisata. Tempat menginap ini merupakan rumah warga yang telah diseleksi sesuai kriteria yang telah ditentukan antara lain harus memiliki pasokan air yang cukup, kamar mandi yang bersih, tersedia kamar kosong, pemilik rumah harus ramah, dan rumah tidak berdebu. Rumah warga yang sesuai kriteria ini akan dipilih menjadi tempat menginap atau disebut homestay.

Fasilitas homestay ini juga sudah dimulai oleh warga Dusun Goha 2. Lokasi Dusun Goha 2 dekat dengan Situ Cisanti, sehingga tamu yang ingin menginap selama beberapa hari bisa menginap di rumah yang telah disediakan. Ada 4 rumah yang mampu menyediakan homestay untuk pendatang dengan kapasitas 2 hingga 40 orang. Homestay yang dimaksud adalah tempat menginap yang dengan kamar terpisah dari rumah utama pemilik (atau bahkan terpisah rumah tapi masih berdekatan), disediakan makan sesuai permintaan, dan disediakan kamar mandi. Homestay di Dusun Goha 2 diperuntukkan kepada pendatang seperti peserta KKN dan peneliti dengan durasi menginap sekitar tiga hari hingga satu bulan. Kisaran biaya yang dikenakan untuk homestay di Dusun Goha 2 adalah Rp. 50.000 - Rp. 100.000 per orang per malam untuk biaya menginap, serta tambahan Rp. 15.000 per orang untuk satu kali makan. Sedangkan homestay di Babakanranca baru digunakan untuk peserta edukasi wisata berbasis alam.

Pengadaan homestay ini sudah berlangsung sejak 2016 dan berawal dari ketidaksengajaan pihak desa yang meneruskan laporan kepada warga bahwa ada yang ingin menginap di Dusun Goha 2. Setelah laporan tersebut, hingga sekarang, penyediaan homestay masih berlangsung. Tetapi homestay ini baru bisa ditemukan apabila pengunjung melapor ke kantor desa untuk menginap kemudian diarahkan ke beberapa rumah, atau hasil mouth to mouth dari orang yang dikenal sebelumnya. Tidak ada semacam papan penanda homestay atau ciri khusus di depan rumah yang menyediakan tempat menginap ini. Sejauh ini belum ada pendatang yang sengaja menginap hanya untuk berwisata ke Situ Cisanti, karena biasanya wisatawan mengunjungi Situ Cisanti hanya beberapa saat saja kemudian melanjutkan perjalanan ke tempat lain atau kembali ke penginapan di lokasi lain misalnya di Pengalengan. Rute perjalanan yang 
biasanya ditempuh wisatawan adalah meliputi Bandung - Jelekong - Cisanti - Cibolang Cileunca - Gunung Puntung (Cimaung) - kembali ke Bandung.

Kembali pada bahasan potensi wisata di Desa Tarumajaya, sebelumnya disebutkan bahwa ada beberapa kawasan lain seperti Curug Lodaya Barat, Situs Batu Korsi, dan Situs Batu Kasur yang berada di Dusun Pilar yang berpeluang dikembangkan menjadi lokasi wisata. Namun, lokasi wisata ini belum banyak diketahui orang luar karena memang letaknya yang sulit diakses oleh kendaraan bermotor. Untuk menuju lokasi ini, pengunjung harus menyusuri kebun teh dengan kontur jalan yang separuh sudah diberi semen dan separuhnya lagi masih berbatu. Tidak ada penanda jalan yang memberi keterangan bahwa ada jalur menuju lokasi. Penanda jalan ini baru bisa ditemukan di dekat Dusun Pilar setelah menyusuri kebun teh. Rute ini hanya diketahui oleh penduduk setempat sehingga harus bertanya dulu kepada mereka untuk sampai ke tempat ini.

Potensi wisata ini sebenarnya sudah disadari oleh aparatur desa dan warga lokal, tetapi belum dipromosikan seperti gencarnya promosi untuk Situ Cisanti. Hal ini disebabkan karena lokasi curug dan situs tersebut jauh dari jalan raya serta belum ada instruksi pemerintah untuk mengembangkan curug dan situs di sana. Situ Cisanti pun baru bisa didengar seperti sekarang karena ada perintah kepada TNI untuk merawat dan mengelola selama tujuh tahun. Sehingga, ada kemungkinan bahwa curug dan lokasi baru bisa terkenal apabila dikelola dengan cara yang sama seperti Situ Cisanti.

Selain potensi wisata alam, Desa Tarumajaya juga memiliki hasil perkebunan sayuran seperti kol, kentang, wortel, dan bawang daun, serta peternakan sapi perah. Potensi ini sebenarnya bisa dikembangkan seiring pengembangan lokasi wisata untuk dijadikan oleh-oleh khas Desa Tarumajaya. Kentang bisa diolah menjadi kripik kentang, wortel bisa diolah menjadi manisan wortel, susu bisa diolah menjadi susu murni, susu aneka rasa, yoghurt dan keju, yang kemudian bisa dijual di sekitar lokasi wisata. Akan tetapi, penjualan produk olahan ini belum bisa berkelanjutan karena masyarakat desa masih menjual hasil kebun mentah langsung ke pengepul. Susu yang dihasilkan peternak juga langsung diserahkan ke KPBS Pengalengan yang memiliki pos di Dusun Goha 2 atau petugas KPBS Pengalengan yang mengambil ke rumah peternak.

Selain itu, Desa Tarumajaya juga dikelilingi kawasan perkebunan teh. Tetapi kebun tersebut masih dimiliki oleh perusahaan, sehingga warga sekitar hanya menjadi pegawai seperti pemetik teh, sopir truk pengangkut teh, operator, dan juga petugas keamanan. Para pegawai kebun teh ini diberikan fasilitas rumah yang memiliki pekarangan dan ditanam dengan kol, 
kentang dan bawang daun bergantian selama 3 bulan sekali. Hasil kebun ini bisa dikonsumsi sendiri atau dijual, dan tidak ada kewajiban untuk memberi setoran kepada pabrik karena merupakan fasilitas rumah karyawan. Harga yang didapatkan dari penjualan hasil kebun ini berkisar Rp. 500.000 hingga Rp. 1.000.000 untuk satu kali panen. Luas pekarangannya bisa mencapai $5 \mathrm{~m}^{2}$ untuk masing-masing rumah.

Berdasarkan hasil pengamatan, belum ada kios atau toko yang menjual produk olahan hasil kebun. Padahal kebun sayuran mudah ditemukan di sekitar rumah warga. Untuk hasil ternak, ada satu kios di Dusun Goha 1 yang sudah menjual susu murni dan olahan. Kios ini adalah milik warga, bukan milik KPSB Pengalengan tetapi milik warga yang diberi nama Wayang Windu. Susu yang dijual hanya bisa bertahan selama tiga hari di lemari pendingin atau lima jam di suhu ruang. Produk yang disediakan antara lain susu murni mentah, susu murni matang original, susu murni aneka rasa, yoghurt, keju mozzarella, dodol susu, permen susu, dan kerupuk susu. Produk-produk ini dijual dengan rentang harga Rp. 3.000 - Rp. 30.000. Pemasaran hasil olahan susu ini dengan cara penjualan offline di toko, online melalui instagram, serta melayani pengantaran untuk kawasan Kertasari dan Ciparay.

Kesadaran untuk mengolah hasil panen kebun dan ternak rupanya belum digencarkan oleh pemerintah desa. Sebenarnya sudah cukup sering dilaksanakan pelatihan, setidaknya satu tahun sekali, yang dilakukan oleh universitas-universitas di sekitar Bandung. Mereka bekerja sama dengan desa untuk mengadakan penyuluhan seperti mengenal potensi-potensi yang dimiliki desa, bagaimana cara mengolahnya, dan apa saja keuntungannya. Namun, upaya pelatihan ini dianggap kurang tepat sasaran karena saat itu pesertanya adalah para perangkat desa saja, tidak melibatkan warga yang lain. Desa Tarumajaya juga sudah memiliki pokdarwis tetapi belum jelas keberlanjutannya.

Menurut Dodds (2016), terdapat enam elemen kunci dalam praktek CBT (Community Based Tourism). Analisis praktek CBT di Desa Tarumajaya menggunakan keenam elemen kunci tersebut, adalah sebagai berikut.

Perencanaan partisipatif dan pengembangan kapasitas - untuk memperkuat keterampilan manajemen pariwisata masyarakat. Berdasarkan penuturan ketua RT dan RW keterlibatan mereka dalam pelaksanaan tata kelola desa masih berupa untuk memenuhi kebutuhan internal desa, biasanya bintek (pembinaan teknologi) untuk mengoptimalkan peran mereka sebagai ketua RT/RW. Untuk kepentingan pariwisata, desa masih mengandalkan ketua pokdarwis saja misalnya terkait bagi hasil pendapatan dari kunjungan Situ Cisanti. 
Kolaborasi dan kemitraan yang memfasilitasi hubungan ke pasar - untuk memastikan kelangsungan keuangan. Sudah ada program yang bekerja sama dengan salah satu CSR perusahaan untuk mengembangkan wisata edukasi berbasis alam. Tetapi untuk potensi lainnya seperti curug, situs, dan homestay belum ada upaya kolaborasi dengan pihak terkait.

Pengelolaan/pemberdayaan masyarakat lokal. Desa Tarumajaya sudah mempunyai pokdarwis dan juga menerima pelatihan dari beberapa pihak penyelenggara. Tetapi keberlangsungan pokdarwis masih dipertanyakan karena belum ada aktivitas yang produktif seperti pengolahan hasil kebun dan ternak untuk dijadikan buah tangan bagi para pengunjung lokasi wisata.

Penciptaan tujuan lingkungan/masyarakat - untuk memastikan kesesuaian dengan nilai-nilai masyarakat. Pemeliharaan lingkungan ditemukan di Babakanranca dengan cara pengolahan sampah dan juga pembuatan biogas dari kotoran sapi. Tetapi upaya ini belum sepenuhnya dilakukan di seluruh area Desa Tarumajaya. Program ini masih digagas oleh warga di sana belum terintegrasi dengan program desa.

Bantuan dari enabler (pemerintah, lembaga pendanaan dan sektor swasta) - untuk memfasilitasi akses ke ekonomi formal Pemerintah merilis program Citarum Harum sekaligus memberi perintah kepada TNI untuk menjadi pengelola di sana. Mereka melakukan pemeliharaan alam seperti menghimbau agar tidak merusak tanaman di sekitar Situ Cisanti dan juga melakukan pembibitan di sekitar kaki gunung. TNI disebar di 70 sektor di sekitar Desa Tarumajaya. Selain program ini, belum ada bantuan lain misalnya pemberian dana untuk pengembangan pariwisata dan sebagainya.

Pendapatan tambahan untuk keberlanjutan komunitas jangka panjang Menyediakan penginapan bertajug homestay yang berada di Dusun Goha 2 dan Babakanranca. Hasil pendapatan dari penyediaan homestay secara penuh diberikan kepada pemilik rumah (tidak ada bagi hasil dengan pemerintah desa). Adanya kios penjualan hasil pengolahan susu sapi di Dusun Goha 1 yang menyediakan berbagai ragam produk olahan dari susu. Usaha lainnya belum ditemukan, seperti olahan hasil kebun, karena hasil panen langsung dijual kepada pengepul.

\section{Kesimpulan}

Desa Tarumajaya memiliki potensi ekowisata yang sangat mumpuni. Situ Cisanti yang merupakan titik 0 kilometer Sungai Citarum merupakan objek ekowisata yang sangat strategis. Berbagai pihak, termasuk di dalamnya pemerintah pusat terlibat langsung dalam pengelolaan Situ Cisanti. Selain Situ Cisanti, Desa Tarumajaya juga memiliki berbagai objek wisata lainnya 
yang tidak kalah menarik. Bumi perkemahan, perkebunan teh, dan lansekap pertanian, menawarkan pengelaman berwisata yang sangat menarik. Praktek ekowisata saat ini sudah dilakukan di Desa Tarumajaya. Meskipun elemen-elemen kunci Community Based Tourism sudah dilakukan dalam praktek ekowisata di Desa Tarumajaya, namun belum memadai. Berbagai usaha masih harus dilakukan, terutama agar ekowisata di Desa Tarumajaya mampu memberikan alternative sumber matapencaharian bagi warga, yang notabene adalah petani tanpa lahan. Kegiatan ekowisata yang berlandaskan CBT diharapkan mampu mengurangi ketergantungan warga atas lahan, terutama lahan konservasi.

\section{Ucapan Terimakasih}

Artikel ini disusun berdasarkan data yang dikumpulkan melalui survey yang dibiayai oleh PPM DRPMI Universitas Padjadjaran tahun 2019 dengan Judul: Pemberdayaan Sosial Budaya dan Ekonomi Maasyarakat dalam Implementasi Pembangunan Pariwisata Ekologi (ecotourism).

\section{Pustaka}

BPS Kabupaten Bandung, 2017.

R. Dodds, A. Ali, K. Galaski. (2016). Mobilizing Knowledge: Key elements of success and barriers in community based tourism. Current Issues in Tourism, 1-27.

Suansri, P. (2003). Community Based Tourism Handbook. Responsible Ecological Social Tour - REST. 